\title{
PRODUCTION OF ANTIMICROBIAL AND ANTICANCER FOM FEATHER-KERATINOLYTIC NOCARDIOPSIS SP. 28ROR AS A NOVEL STRAIN USING FEATHER MEAL MEDIUM
}

\author{
RABAB OMRAN \\ Biology Department, College of Science, University of Babylon, Babil, Al-Hillah, Iraq \\ Email: sci.rabab.omran@uobabylon.edu.iq
}

Received: 01 Dec 2016 Revised and Accepted: 17 Jan 2017

\begin{abstract}
Objective: Production of bioactive secondary metabolites from a feather-degrading actinobacterial species using feather meal medium.

Methods: Protease producer actinobacterial isolates (22) recovered from farm soil, poultry farm soil and feather wastes were used to test the antagonistic effect on pathogenic bacteria and fungi, including Staphylococcus aureus, Escherichia coli, Microsporum canis and Trichophyton mentagrophyte using Mueller-Hinton agar and potato dextrose agar (PDA) media. The best isolate was used to produce the active metabolites in feather meal medium composed from (g/l) 10 feather meal, 5 sucrose and 0.3 l cement extract were dissolved in tap water, in addition to the standard medium composting of (g/l) glucose (1\%), tryptone (1\%), $\mathrm{KH}_{2} \mathrm{PO}_{4}(0.07 \%)$ and $\mathrm{K}_{2} \mathrm{HPO}_{4}(0.14 \%)$ were dissolved in distilled water, both of them at initial pH 9 . The secondary metabolites were partially purified by Sephadex LH20 column and the antimicrobial activity and cytotoxic activity were assayed.
\end{abstract}

Results: $31.82 \%$ of isolates inhibited the growth of both bacterial and fungal test organisms and the best one was Nocardiopsis sp. 28ROR (GenBank: KC702802.1) at a significant level $P<0.05$. It produced bioactive metabolites in both feather meal broth and the standard media. The partially purified metabolites inhibit the breast cancer cell line MCF-7 (51\%) and normal hepatic cell line WRL-68 (9\%), in addition to inhibiting $S$. aureus andTrichophyton menta agrophyte growth.

Conclusion: The actinobacteria has vast abilities to degrade very complex wastes and converted to simple constituents to reprocess in other industries. So the Nocardiopsis sp. 28ROR was a novel strain produced anticancer, antimicrobial substances using feather meal medium as a cheap waste medium.

Keywords: Nocardiopsis, Keratinase, Antimicrobial, Anticancer, Feather medium

(C) 2016 The Authors. Published by Innovare Academic Sciences Pvt Ltd. This is an open access article under the CC BY license (http://creativecommons.org/licenses/by/4. 0/) DOI: http://dx.doi.org/10.22159/ijpps.2017v9i3.16426

\section{INTRODUCTION}

The genus Nocardiopsis produced a vast variety of bioactive compounds such as pendolmycin (antifungal and tumor promoting agent), in addition to secreting extracellular enzymes like alkaline tolerant enzymes, amylases, alkaline serine proteases and keratinolytic proteases $[1,2]$. Nocardiopsis species produced a novel antibiotic like naphthospironones (antimicrobial and anticancer compounds) [3], apoptolidins (selective anticancer agents) [4], griseusins (antimicrobial and anticancer compounds) [5], thiopeptides (antibiotic) [6] and lipopeptides (surfactants) [7]. This actinobacterium is thus of considerable biotechnological importance and can serve as potential sources of natural products and new metabolites in the future. On the other hand, some of actinobacterial species had ability to degrade the feather waste, which are the valuable sources for variety of amino acids, predominantly cystine, lysine, proline, and serine [8], because of these abilities of actinobacteria particularly Nocardiopsis it may be used to produce the antibiotics using feather waste degradation as a sources for carbon and nitrogen $[9,10]$. So our objective of the study was using keratinase producing action bacteria to produce antimicrobial substances in a culture medium containing feather waste as a cheap medium.

\section{MATERIALS AND METHODS}

\section{Materials}

The materials were provided from Biotechnology and Genetic Engineering laboratory at the University of Babylon. Analytical grade solvents and Mueller-Hinton agar (HiMedia, India). Sephadex G-50 superfine gel and Sephadex G-25 superfine gel (Pharmacia Biotech). Glucose, tryptone, $\mathrm{KH}_{2} \mathrm{PO}_{4}$ and $\mathrm{K}_{2} \mathrm{HPO}_{4}$ (BDH, England).

\section{Feather meal preparation}

Feather meal was prepared from native chicken feathers as described by Saibabu et al. [11] with slight modifications. White feather waste was collected from poultry slaughterhouses, and it was washed several times with soap and water to eliminate blood and dirt remainder, and then dried for $24 \mathrm{~h}$ in sunlight. The feathers were cut with scissors into small pieces of $1-3 \mathrm{~cm}$ long. Defatting of feather pieces was performed by soaking them in a mixture of chloroform: methanol (1:1) for $2 \mathrm{~d}$, followed by chloroform: acetone: methanol $(4: 1: 3)$ for $2 \mathrm{~d}$. The solvent was replaced every day. The feathers were finally washed several times with tap water to eliminate the solvent residual, dried using the oven at $40{ }^{\circ} \mathrm{C}$ for $24 \mathrm{~h}$, ground using an electric blender and used as feather meal.

\section{Actinobacterial isolates}

Twenty-two keratinase producing actinobacterial isolates were screened for antimicrobial production, which previously isolated from different sources such as farm soils, soils of a poultry farm and waste chicken feathers (unpublished data) in Biotechnology and Genetic Engineering Laboratory at the University of Babylon in Babylon Province.

\section{Screening for antimicrobial activity}

Preliminary screening for antibacterial activity was done by the cross-streak method [12], on potato dextrose agar (PDA) medium and Mueller-Hinton agar (MHA) using pathogenic Gram positive and negative bacteria as test organisms including Staphylococcus aureus and Escherichia coli. Whereas primary screening of antifungal activity was performed according to Crawford et al. [13] method using PDA medium and Microsporum canis and Trichophyton menta agrophyte as test pathogenic fungi. All pathogenic isolates were obtained from Biotechnology laboratory at Babylon University.

Also, the antimicrobial activities were assayed according to agar well diffusion method was performed [14] using the MuellerHinton agar medium for $S$. aureus and potato dextrose agar for T. mentagrophyte. The inoculum of test organisms was prepared separately by mixing a three microorganism colonies $(1 \mathrm{ml})$ from the exponential phase 
with $9 \mathrm{ml}$ of sterile nutrient broth and compared the turbidity with that of the standard 0.5 McFarland solution which is equivalent to 106-108 CFU/ml. The sterile swab was dipped into suitably adjusted inoculum. The entire MHA and PDA surfaces were swabbed evenly by the cotton swab. The inoculated plates were left at room temperature for 3-5 min to absorb surface moisture before well formed. The wells $(6.0 \mathrm{~mm}$ diameter, $2.0 \mathrm{~cm}$ apart) were formed in a medium using a sterile cork borer, and then $100 \mu \mathrm{l}$ of filtered of Nocardiopsissp. 28 ROR broth was loaded into each well for the assay of antagonistic activity. The plates were pre-incubated at $4{ }^{\circ} \mathrm{C}$ for $2 \mathrm{~h}$ to allow uniform diffusion into the agar. Later, the plates were incubated in suitable conditions for test organisms' growth at $37{ }^{\circ} \mathrm{C}$ for $18 \mathrm{~h}$ ( $S$. aureus) and $28{ }^{\circ} \mathrm{C}$ for $3 \mathrm{~d}$ (T. mentagrophyte). The antimicrobial activity was evaluated by the measuring of inhibition zone diameters.

\section{Production and extraction of active metabolites}

The antimicrobial metabolites were produced using two different media $(100 \mathrm{ml})$, the first one as an optimal production medium for antibiotics from the 28ROR strain [15] was composed (g/l) from glucose $(1 \%)$, tryptone $(1 \%) \mathrm{KH}_{2} \mathrm{PO}_{4}(0.07 \%)$ and $\mathrm{K}_{2} \mathrm{HPO}_{4}(0.14 \%)$ were dissolved in distilled water at initial $\mathrm{pH}$ 9. The second was a modified medium feather meal-cement extract medium composed from (g/l) 10 feather meal, 5 sucrose and 0.31 cement extract, which were mixed well together and completed to $1 \mathrm{l}$ by tap water after adjusted to $\mathrm{pH} 9$. Both sterilised media were inoculated with $5 \%$ of culture suspensions (OD 0.5 at $600 \mathrm{~nm}$ ) of the actinobacterial strain (28ROR) inoculum, and then incubated at $35^{\circ}$ for 14-21d. Subsequently, the secondary metabolites were harvested by cooling centrifuge at $4{ }^{\circ} \mathrm{C}$ and $10000 \mathrm{rpm}$ for $15 \mathrm{~min}$ and the antimicrobial activities were assayed.

\section{Partial purification of active secondary metabolites}

The culture filtrate of both media was separately concentrated by rotary evaporator at $40{ }^{\circ} \mathrm{C}$. The concentrated filtrates $(50 \mathrm{ml})$ were fractionated by adding $40 \%$ saturation of ammonium sulfate, and 30 $\mathrm{ml}$ concentrated cooled acetone $\left(-20^{\circ} \mathrm{C}\right)$, mixed well by vortex, leave to stand for $15-30 \mathrm{~min}$ in ice-bath, then centrifuged at $4{ }^{\circ} \mathrm{C}$ and 10 $000 \mathrm{rpm}$ for $15 \mathrm{~min}$, followed three phase formation, the salt phase (lower layer), acetone (upper layer) and the protein layer floated within acetone phase. Protein precipitate was separated by cooling centrifugation at $10000 \times \mathrm{g}$ for $10 \mathrm{~min}$. This step to precipitate proteins and polypeptides and the antimicrobial metabolites were soluble in acetone phase. The protein precipitate dissolved in $20 \mathrm{ml}$ Tris buffer and keratinase activity was assayed [16] and store in-24 ${ }^{\circ} \mathrm{C}$. The acetone phases which containing the antimicrobial metabolite were evaporated by the oven at $35^{\circ} \mathrm{C}$. The concentrated solutions were partially purified by gel filtration column chromatography using two steps the first one by Sephadex G-50 superfine gel (fractionation range of Sephadex G-50: 1 500-30 000 Daltons), then Sephadex G-25 superfine gel (Pharmacia Biotech), which separated biological products within fractionation range 1 000-5 000 Daltons. The columns were prepared according to Pharmacia Biotech methods [16]. The gel filtration was performed by Sephadex G-50 column (D x l) $1.9 \times 50 \mathrm{~cm}$ using $0.02 \mathrm{M}$ phosphate buffer at pH8 as running buffer, $2 \mathrm{ml}$ of concentrated sample was loaded onto the column, the fractions recovered from column at 60 $\mathrm{ml} / \mathrm{h}$ flow rate and the fractions were collected at $3 \mathrm{ml}$ size volume. After that, the absorbance of fractions was read at $280 \mathrm{~nm}$ and the antimicrobial activities were assayed [14]. The active fractions were combined, concentrated and loaded (2 ml) into a Sephadex G-25 column $(1 \times 62 \mathrm{~cm})$, then it was eluted by phosphate buffer $0.02 \mathrm{M}$ at pH8 and collected fractions at flow rate $60 \mathrm{ml} / \mathrm{h}$ and $3 \mathrm{ml}$ fraction volume. Subsequently, the absorbance of fractions at $280 \mathrm{~nm}$ was read, and the antimicrobial activities were assayed [14]. After that, the active fractions were combined and dried in a vacuum dryer, then known the weight of dried substances (100-1000 $\mu \mathrm{g}$ ) were dissolved in DMSO (dimethyl sulfoxide) for further investigation. The antimicrobial activities of partial purified actinobacterial metabolites were assayed according to agar well diffusion method was performed [14] using the MHA medium for $S$. aureus and PDAfor T. mentagrophyte, each well loaded by $100 \mu \mathrm{l}$ of $1 \mathrm{mg} / \mathrm{ml}$ of partially purified metabolites, as well as the cytotoxic activity was assayed.

\section{Cytotoxic activity assay}

MTT assay was performed according to the references $[18,19]$ at the Centre for Natural Products Research and Drug Discovery, Department of Pharmacology, Faculty of Medicine, University of Malaya/Kuala Lumpur, Malaysia.

The cell viability was determined by colorimetric assay using 3-[4,5dimethylthiazoyl]-2, 5-diphenyltetrazolium bromide (MTT dye), two kinds of cells were used the human breast cancer cell line (MCF-7cell line) and the normal human hepatic cells (non-tumorigenic fetal hepatic cell line WRL-68). Briefly, $100 \mu \mathrm{l}$ cell suspension was added to the flat-bottomed microculture plate wells, each cell line on a separate plate were treated with $100 \mu \mathrm{l}$ microbial extract, incubated for $24 \mathrm{~h}$, and centrifuged to remove the dead cells. An aliquot of $100 \mu \mathrm{l}$ from $2 \mathrm{mg} / \mathrm{ml}$ MTT dye was added to each well and incubation was continued for a further $4 \mathrm{~h}$, then $50 \mu \mathrm{l}$ of solubilization solution of DMSO was added to each well. The experiment was performed in triplicate. After complete solubilization of the dye, the absorbance of the coloured solution obtained from living cells was read at $620 \mathrm{~nm}$ with an ELISA reader. The mean absorbance for each group of replicates was calculated. The control was the non-treated cultures in all experiments that contained cells in the medium only.

Calculate percent viability by using formula [18]:

$$
\% \text { Cell viability }=\frac{\text { Live cell count }}{\text { Total cell count }} \times 100
$$

\section{Data analysis}

Data were analyzed using SPSS version 22 software Fisher's exact and T-test and ANOVA one way with a significant $P$ value of $<0.05$.

\section{RESULTS AND DISCUSSION}

\section{Primary screening of active metabolite production}

The ability of produce antimicrobial metabolites from protease producing actinobacterial isolates were investigated, $59.00 \%$ of isolates appeared antifungal activity against both test organisms ( $M$. canis and T. mentagrophyte), whereas $31.82 \%$ of the isolates showed antibacterial activity against $E$. coli and $22.73 \%$ against $S$. aureus (table $1)$. The best one $(P<0.05)$ was selected to produce antimicrobial substances (the isolate $28 \mathrm{ROR}$ ). These results in consensus with previous studies that documented the actinobacterial species are the main sources for producing antimicrobial substances and the same organisms had the ability to produce antifungal, antibacterial and anticancer substances [2, 3, 20-24].

The potential isolates 28 ROR which recovered from poultry farm soil, and identified depending phenotypes and physiological characteristics and molecular bases using partial sequencing of the $16 \mathrm{~S}$ rRNA gene and the phylogenetic tree was constructed by the neighbor-joining method for comparison of the 16S $\mathrm{r}$ RNA gene sequences, indicated that the strain belonged to the genus Nocardiopsis (the accession number KC702802.1) and named Nocardiopsis sp. 28ROR (unpublished data).

The selected strain Nocardiopsis sp. 28ROR produced two types of keratinase (acid and alkaline) at different $\mathrm{pH}$ values ( 6 and 10) also the optimum activities of these enzymes at $\mathrm{pH} 6.0$ and 10.0 (unpublished data). Also, the strain 28ROR had the ability to produce antibacterial, antifungal and anticancer in both standard and feather meal media.

From our preliminary results, we can conclude the modified medium (feather meal-cement extract) as a cheap medium gave a good result for the production of bioactive metabolite substances and could be optimized for over-production. Logically, the strain 28ROR produced keratinase enzymes that active within wide range of $\mathrm{pH}$ values and hydrolyzed completely feather meal to amino acids and small peptides after $14 \mathrm{~d}$, this lysate (soluble portions) was rich in most of the amino acids like cysteine, alanine, glycine, serine and others, also it contained soluble amides [25] and it utilized as carbon and nitrogen sources for its growth, metabolisms, and produced the secondary metabolites like antimicrobial and anticancer substances. Also, the production media supplemented with basic minerals, 
including buffer salts, to enhance bacterial growth, enzyme production and overcome the changing of the initial $\mathrm{pH}$ of media. In our study, cement extract was used as a source of minerals, and it acts as a strong alkaline buffer to prevent the initial $\mathrm{pH}$ value changes by the byproducts of microorganism. Because of the cement extract was rich with some alkaline minerals like calcium oxides and other metal oxides such as magnesium, ferric, aluminium and sulfurs [26].

Table 1: Antimicrobial antagonism of actinobacterial isolates

\begin{tabular}{|c|c|c|c|c|}
\hline \multirow[t]{2}{*}{ Isolates } & \multicolumn{4}{|c|}{ Test organism $(\mathrm{mm} \pm \mathrm{SD})$} \\
\hline & M. canis & T. mentagrophyte & E. coli & S. aureus \\
\hline 1 & $22 \pm 0.11$ & $11 \pm 0.05$ & 0 & 0 \\
\hline 2 & $23 \pm 0.11$ & $12 \pm 0.05$ & $13 \pm 0.17$ & 0 \\
\hline 3 & 0 & 0 & 0 & $11 \pm 0.05$ \\
\hline 4 & 0 & 0 & 0 & 0 \\
\hline 5 & 0 & 0 & 0 & 0 \\
\hline 6 & $12 \pm 0.05$ & $11 \pm 0.05$ & $32 \pm 0.17$ & 0 \\
\hline 7 & 0 & 0 & 0 & 0 \\
\hline 8 & 0 & 0 & 0 & $12 \pm 0.11$ \\
\hline 9 & 0 & 0 & 0 & 0 \\
\hline 10 & $22 \pm 0.11$ & $10 \pm 0.05$ & $21 \pm 0.17$ & 0 \\
\hline 14 & 0 & 0 & 0 & 0 \\
\hline 16 & $13 \pm 0.11$ & $12 \pm 0.15$ & 0 & 0 \\
\hline 17 & $13 \pm 0.11$ & $31 \pm 0.11$ & $22 \pm 0.05$ & 0 \\
\hline 18 & $22 \pm 0.05$ & $12 \pm 0.11$ & 0 & $11 \pm 0.11$ \\
\hline 20 & $23 \pm 0.11$ & $11 \pm 0.05$ & 0 & 0 \\
\hline 21 & 0 & 0 & 0 & $12 \pm 0.11$ \\
\hline 25 & $23 \pm 0.17$ & $22 \pm 0.17$ & 0 & 0 \\
\hline 26 & $31 \pm 0.11$ & $23 \pm 0.11$ & 0 & 0 \\
\hline 27 & $11 \pm 0.17$ & $21 \pm 0.11$ & $12 \pm 0.05$ & 0 \\
\hline $28^{*}$ & $24 \pm 0.17$ & $33 \pm 0.17$ & $13 \pm 0.05$ & $23 \pm 0.17$ \\
\hline 29 & 0 & 0 & $21 \pm 0.11$ & 0 \\
\hline 30 & $12 \pm 0.05$ & $21 \pm 0.05$ & 0 & 0 \\
\hline $100 \%$ & 59.00 & 59.00 & 31.82 & 22.73 \\
\hline
\end{tabular}

Antagonism screening for antibacterial activity was done by the cross-streak method [12] on MHA medium, and for antifungal activity was done depending on Crawford et al. [13] method using PDA medium. Antagonism ( $\mathrm{mm} \pm \mathrm{SD}$ ), SD Standrd Diveation and 0: no inhibition. * Statistically significant a level $P<0.05$.

\section{Production and extraction of active secondary metabolites}

The secondary metabolites were produced from the strain 28ROR using two media, including optimal antimicrobial production medium as a standard medium and the second was modified feather mealcement extract medium. Although, the product in standard media was higher than modifying medium $(\mathrm{P} \leq 0.05)$, but the modified medium was cheaper and available in an environment as a waste. The metabolite substances were extracted from both media using threephase of extraction methods using ammonium sulfate and acetone and the active metabolites located within acetone layer, which was separated and concentrated using a rotary evaporator, and then they were partially purified using gel filtration chromatography [16] by two steps, Sephadex G-50 column (fig. 1), followed a Sephadex G-25 column (fig. 2). In the first step, the high molecular weight of polypeptides over 30000 Daltons was separated from the low molecular weights of metabolite substances, which were eluted within the void volume of the column.

Subsequently, the active fractions were separated by a Sephadex G25 column and the active fractions were investigated for antimicrobial activities and cytotoxic activity. These results in consensus with previous studies that documented the antimicrobial substances could be purified by many methods like chromatography methods depending on the physical characteristics, chemical structure and molecular weight of the antibiotics [27-29].

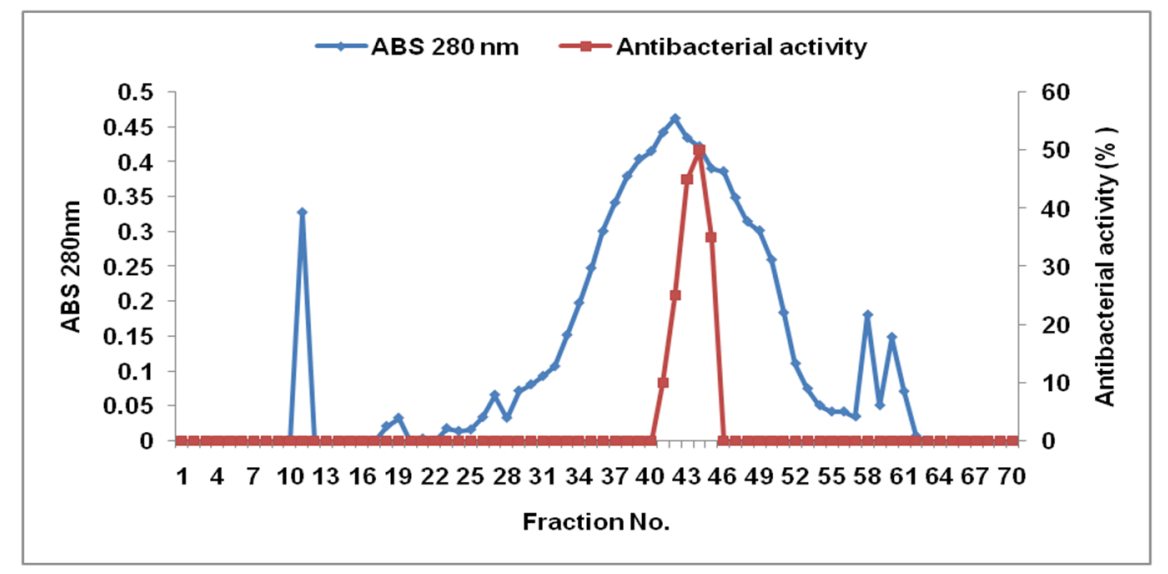

Fig. 1: Gel filtration chromatography of feather meal-cement broth filtrate using Sephadex G-50 columns

The gel filtration was performed using $0.02 \mathrm{M}$ phosphate buffer at $\mathrm{pH} 8$, column (D xl) $1.9 \times 50 \mathrm{~cm}$, void volume $\left(\mathrm{V}_{\mathrm{o}}\right)=32 \mathrm{ml}$ (fraction No.11), Total volume $\left(\mathrm{V}_{\mathrm{t}}\right)$ $=140 \mathrm{ml}$ (fraction No.47), sample volume $=2 \mathrm{ml}$, flow rate $=60 \mathrm{ml} / \mathrm{h}$, fraction volume $=3 \mathrm{ml}$, fractionation range of Sephadex G-50: $1500-30000$ Daltons. 


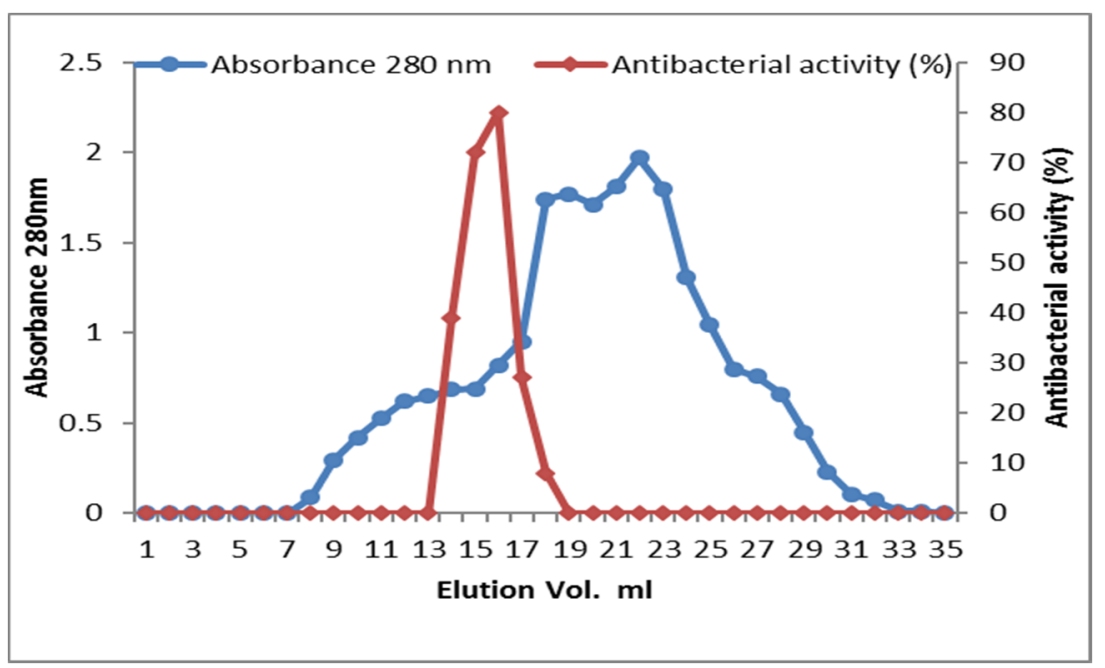

Fig. 2: Antibacterial substance separation by Sephadex G-25 column chromatography after Sephadex G-50 column from feather mealcement broth filtrate

The gel filtration was performed using $0.02 \mathrm{M}$ phosphate buffer at pH8, column (D x l) $1 \times 62 \mathrm{~cm}$, void volume $\left(\mathrm{V}_{\mathrm{o}}\right)=14.6 \mathrm{ml}$ (fraction No.5), Total volume $\left(V_{t}\right)=49 \mathrm{ml}$ (fraction No.17), sample volume $=2$ $\mathrm{ml}$, flow rate $=60 \mathrm{ml} / \mathrm{h}$, fraction volume $=3 \mathrm{ml}$, fractionation range of Sephadex G-25: 1 000-5 000 Daltons.

In this experiment, the secondary metabolites were harvested after 21d because of these metabolites were accumulated in culture filtrate and keratinase enzymes were reduced about $90 \%$. After that, the bioactive metabolites were extracted using the salt-solvent mixture to remove protein precipitate and recover only solvent soluble molecules of metabolites, amino acids and small peptides from acetone layer. Subsequently, the active products concentrated by evaporation and partially purified by gel filtration [17]. The recovered amino acids and small peptides could be used as a fertilizer or supplement to microbial media, in addition to the active metabolite substances having a low molecular weight less than 5000 Daltons, which used as antimicrobial and anticancer substances after further characterization and study the mode of actions.

The antimicrobial activity assayed against $S$. aureus and $T$. mentagrophyte according to agar well diffusion method. The results revealed that the strain 28ROR produced antimicrobial substances in both media after $7 \mathrm{~d}$ and were increasing until $21 \mathrm{~d}$ and the production of antibacterial substances was higher in the standard medium than modified medium (17 $\mathrm{mm}$ and $13 \mathrm{~mm}$ respectively), whereas the antifungal substances were relatively the same $(12$ $\mathrm{mm})$.

Also, cytotoxic activity was assayed by MTT method using the human breast cancer cell line (MCF-7cell line) and the normal human hepatic cells (non-tumorigenic fetal hepatic cell line (WRL68 ) and the results appeared the partially purified culture extract had cytotoxic activity as showed in the table (2). From our results the partially purified metabolite $(400 \mu \mathrm{g} / \mathrm{ml})$ had the ability to inhibit breast cancer cell line (MCF-7) at a percentage between 4451 whereas it slightly inhibited normal hepatic cell line (WRL-68) at $9 \%, P=0.0005)$. The above results indicate that the Nocardiopsis $s p$. 28ROR is a novel strain for production anticancer using feather waste and could be further purification and characterization, in addition to two types of keratinases and antimicrobial metabolites.

Many studies reported that the actinobacterial genera like Nocardiopsis species had the ability to produce a wide spectrum of antimicrobial and anticancer metabolites that had higher ability to inhibit cancer cell lines in comparison with another source like plant products having antioxidant activity and they inhibit cancer cell lines $[1-7,30-33]$.

Table 2: Cytotoxic activity of partially purified extract of Nocardiopsis sp. 28ROR against breast cancer cell line MCF-7 and normal hepatic cell line WRL-68

\begin{tabular}{lcc}
\hline Partially purified extract $(\boldsymbol{\mu g} / \mathbf{m l})$ & MCF-7 mean \pm SD & WRL-68 mean \pm SD \\
\hline Feather meal medium & & \\
400 & $56.28 \pm 5.61$ & $91.74 \pm 1.81$ \\
200 & $90.15 \pm 1.02$ & $92.78 \pm 1.70$ \\
100 & $91.74 \pm 1.82$ & $94.44 \pm 0.12$ \\
50 & $92.78 \pm 1.70$ & $95.25 \pm 0.81$ \\
Control medium & & 0.084 \\
400 & $49.16 \pm 0.95$ & $91.77 \pm 0.84$ \\
200 & $88.1 \pm 0.85$ & $94.4 \pm 0.26$ \\
100 & $90.9 \pm 0.24$ & 0.000 \\
50 & $91.23 \pm 1.10$ & 0.000 \\
\hline
\end{tabular}

*All the values are the average of three readings, mean $\pm \mathrm{SD}, \mathrm{SD}=$ Standard Deviation

\section{CONCLUSION}

In the present scenario over the world, academic and industrial research focuses mainly on recycling of waste by using microorganisms that have the ability to degrade the waste like a chicken feather to prevent their accumulation in the environment. In the other hand, the degradable constituents can be reprocessed or utilised as nutrition sources to the same microorganisms to produce commercial substances such as pharmaceuticals or antibiotics after controlling the growth and production parameters for these microorganisms.

The Nocardiopsis sp. 28ROR was a novel strain produced anticancer, antimicrobial substances and two types of extracellular keratinizes (acid and alkaline) in cheap feather waste medium at a wide tolerance range of temperature and pHs. 


\section{ACKNOWLEDGMENT}

I would like to thank the faculty of Biology Department, College of Science, the University of Babylon to provide some research materials and laboratory equipment supplies.

\section{CONFLICT OF INTERESTS}

We declare that we have no conflict of interest

\section{REFERENCES}

1. Bennur T, Kumar AR, Zinjarde S, Javdekar V. Nocardiopsis species as potential sources of diverse and novel extracellular enzymes. Appl Microbiol Biotechnol 2014;98:9173-85.

2. Sun HH, White CB, Dedinas J, Cooper R, Sedlock DM. Methylpendolmycin, an Indo lactam from a Nocardiopsis sp. J Nat Prod 1991;54:1440-3.

3. Ding ZG, Li MG, Zhao JY, Ren J, Huang R, Xie MJ, et al. Naphthospironone a: an unprecedented and highly functionalized polycyclic metabolite from an alkaline mine waste extremophile. Chem Eur J 2010;16:3902-5.

4. Kim JW, Adachi H, Shin-ya K, Hayakawa Y, Seto H. Apoptolidin, a new apoptosis inducer in transformed cells from Nocardiopsis $s p$. J Antibiot 1997;50:628-30.

5. Li YQ, Li MG, Li W, Zhao JY, Ding ZG, Cui XL, et al. Griseusin D, a new pyranonaphthoquinone derivative from a alkaphilic Nocardiopsis sp. J Antibiot 2007;60:757-61.

6. Engelhardt K, Degnes KF, Kemmler M, Bredholt H, Fjaervik E, Klinkenberg G, et al. Production of a new thiopeptide antibiotic TP-1161, by a marine Nocardiopsis species. Appl Environ Microbiol 2010;76:4969-76.

7. Gandhimathi R, Seghal KG, Hema TA, Selvin J, Rajeetha RT, Shanmughapriya S. Production and characterization of lipopeptide biosurfactant by a sponge associated marine actinomycetes Nocardiopsis alba MSA10. Bioprocess Biosyst Eng 2009;32:825-35.

8. Kanchana R. Farm waste recycling through microbial keratinases. J Appl Sci Environ Sanit 2012;7:103-8.

9. Gopinath SCB, Anbu P, Lakshmipriya T, Tang TH, Chen Y, Hashim U. Biotechnological aspects and perspective of microbial keratinase production. BioMed Res Int 2015. http://dx.doi.org/10.1155/2015/140726

10. Gupta R, Ramnani P. Microbial keratinases and their prospective applications: an overview. Appl Microbiol Biotechnol 2006;70:21-33.

11. Saibabu V, Niyonzima FN, More SS. Isolation, partial purification and characterization of keratinase from Bacillus megaterium. Int Res J Biol Sci 2013;2:13-20.

12. Madigan MT, Martinko JM, Stahl DA, Clark DP. Commercial products and biotechnology. In: Brock biology of microorganisms. $13^{\text {th }}$ ed. Boston: Benjamin cumings; 2012. p. 415-6.

13. Crawford DL, Lynch JM, Whipps JM, Ousley MA. Isolation and characterization of actinomycete antagonists of a fungal root pathogen. Appl Environ Microbiol 1993;59:3899-905.

14. Perez C, Pauli M, Bazevque P. An antibiotic assay by the agarwell diffusion method. Acta Biol Med Exp 1990;15:113-5.

15. Omran R, Kadhem MF. Production, purification, and characterization of bioactive metabolites produced from rare actinobacteria Pseudonocardia alni. Asian J Pharm Clin Res 2016;9(Suppl 3):1-9.
16. Wawrzkiewicz K, Lobarzewski J, Wolski T. Intracellular keratinase of trichophyton gallinae. J Med Vet Mycol 1987;25:261-8.

17. Gel filtration: principles and methods. $7^{\text {th }}$ ed. Pharmacia Biotech; 1997.

18. Freshney RI. The culture of an animal cell. 6 ed. Wily-Liss, New York; 2010.

19. Chih PL, Wei JT, Yuang LL, Yuh CK. The extracts from nelumbonucifera suppress cell cycle progression, cytokine genes expression, and cell proliferation in human peripheral blood mononuclear cells. Life Sci 2004;75:699-16.

20. Singh C, Parmar RS, Jadon P, Kumar A. Characterization of actinomycetes against phytopathogenic fungi of glycine max (L.). Asian J Pharm Clin Res 2016;9(Suppl 1):216-9.

21. Nanjwade BK, Chandrashekhara S, Goudanavar PS, Shamarez AM, Manvi FV. Production of antibiotics from soil-isolated actinomycetes and evaluation of their antimicrobial activities. Trop J Pharm Res 2010;9:373-7.

22. Kalyani ALT, Ramya Sravani KM, Annapurna J. Isolation and characterization of antibiotic producing actinomycetes from marine soil samples. Int J Curr Pharm Res 2012;4:109-12.

23. Pandey A, Ali I, Butola KS, Chatterji T, Singh V. Isolation and characterization of actinomycetes from soil and evaluation of antibacterial activities of actinomycetes against pathogens. Int J Appl Biol Pharm Technol 2011;2:384-92.

24. Kumari M, Myagmarjav BE, Prasad B, Choudhary M. Identification and characterization of antibiotic-producing actinomycetes isolates. Am J Microbiol 2013;4:24-31.

25. Harrap BS, Woods EF. Soluble derivatives of feather keratin. 1. Isolation, fractionation and amino acid composition. Biochem J 1964;92:8-18.

26. Bishop M, Bott SG, Barron AR. A new mechanism for cement hydration inhibition: solid-state chemistry of calcium nitrilotris (methylene) triphosphonate. Chem Mater 2003; 15:3074-88.

27. Oskay M. Isolation and purification of two metabolites (KGG32A and KGG32-B) from a soil bacterium, Streptomyces sp., KGG32. Int J Agric Biol 2011;13:369-74.

28. Lorian V. Antibiotics in laboratory medicine. Lippincott Williams and Wilkins. USA; 2005. p. 654.

29. Zhang C, Li S, Tian X, Niu S, Zhang W, Chen Y, et al. Pseudonocardians A-C, new diaza anthraquinone derivatives from a deep-sea actinomycete Pseudonocardiasp. SCSI 01299. Mar Drugs 2011;9:1428-39.

30. Newman DJ, Cragg GM. Natural products as sources of new drugs over the last 25 y. J Nat Prod 2007;70:461-77.

31. Bérdy J. Bioactive microbial metabolites. J Antibiot 2005;58:1-26.

32. Jeena K, Liju VB, Kuttan R. Antitumor and cytotoxic activity of ginger essential oil (Zingiber officinale roscoe). Int J Pharm Pharm Sci 2015; 7:341-4.

33. Herdwiani W, Soemardji AA, Elfahmi I, Tan MI. A review of cinnamon as a potent anticancer drug. Asian J Pharm Clin Res 2016;9:8-13.

How to cite this article

- Rabab Omran. Production of antimicrobial and anticancer fom feather-keratinolytic Nocardiopsis $s p$. 28ror as a novel strain using feather meal medium. Int J Pharm Pharm Sci 2017;9(3):175-179. 